\title{
Prinsip Kebersamaan Dalam Hukum Investasi Undang-Undang Nomor 11 Tahun 2020 Tentang Cipta Kerja: Politik Hukum Kepentingan Investasi Ataukah Kesejahteraan Masyarakat
}

\section{Dewi Sukma Kristianti}

Program Studi Doktor Ilmu Hukum Universitas Katolik Parahyangan, Bandung, Indonesia.

@ : dewi.sukma@unpar.ac.id

doi : $x x x x x x x x x x x x x x x$

\section{Info Artikel \\ Keywords: \\ Principle of Togetherness; \\ Politics of Law; Investment}

Law.

Kata Kunci:

Prinsip Kebersamaan;

Politik Hukum; Hukum

Investasi.

\begin{abstract}
Introductioan: Investment is a necessity that cannot be denied in development activities, especially economic development. This can be seen in studies or in the field of development economics, investment is one of the important factors to obtain capital for the economic development of a country. The goal of development in Indonesia is to realize social justice for all Indonesian people. So that the principle of togetherness is the basis and effort to realize the ideals of welfare and social justice for all Indonesian people.

Purposes of the Research: The purpose of writing this article is to identify and analyze the principle of togetherness as a legal politics of the Job Creation Act in an interdisciplinary manner.

Methods of the Research: The method used in this article uses a normative juridical research method with a multidisciplinary approach.

Findings of the Research: One of the regulations in the investment sector is the Job Creation Law, the principle of togetherness in legal politics that underlies and focuses only on investment interests, so that the goal of realizing social justice is a very long goal. This can be seen from a number of articles in the Job Creation Law, both explicitly and implicitly, indicating several provisions that must be regulated in investment law according to various investment theories.
\end{abstract}

\footnotetext{
Abstrak

Latar Belakang: Investasi menjadi suatu kebutuhan yang tidak dapat ditolak dalam kegiatan pembangunan, khususnya pembangunan ekonomi. Hal ini terlihat dalam studi kajian atau bidang ekonomi pembangunan, investasi merupakan salah satu faktor penting untuk memperoleh modal bagi pembangunan ekonomi suatu negara. Tujuan pembangunan di Indonesia adalah untuk mewujudkan keadilan sosial bagi seluruh rakyat Indonesia. Sehingga prinsip kebersamaan merupakan dasar dan upaya mewujudkan cita-cita kesejahteraan dan keadilan sosial bagi seluruh rakyat Indonesia.

Tujuan Penelitian: Tujuan dari penulisan artikel ini adalah untuk mengetahui dan menganalisis prinsip kebersamaan sebagai politik hukum dari UU Cipta Kerja secara interdisipliner.

Metode Penelitian: Metode yang digunakan dalam artikel ini menggunakan metode penelitian yuridis normatif dengan pendekatan multidisipliner.

Temuan Penelitian: Dalam regulasi di bidang investasi, salah satunya adalah UU Cipta Kerja, prinsip kebersamaan dalam politik hukum yang melatarbelakangi dan menitikberatkan hanya pada kepentingan investasi saja, sehingga tujuan mewujudkan keadilan sosial menjadi
} 
tujuan yang masih sangat panjang. Hal ini terlihat dari sejumlah pasal dalam UU Cipta Kerja, baik secara tersurat maupun tersirat menunjukkan beberapa ketentuan yang harus diatur dalam hukum investasi menurut berbagai teori investasi.

\section{Pendahuluan}

Menurut Pembukaan Undang Undang Dasar Negara Republik Indonesia Tahun 1945 (UUD NRI Tahun 1945), salah satu tujuan kemerdekaan Indonesia adalah memajukan kesejahteraan umum berdasarkan kemerdekaan, perdamaian abadi dan keadilan sosial. Pernyataan tersebut mengisyaratkan bahwa secara konstitusional seluruh kegiatan berkebangsaan dan bernegara, diarahkan pada tujuan untuk menyejahterakan bangsa dan masyarakat Indonesia, tanpa ada yang dikecualikan. Hal ini sesuai dengan apa yang tercantum pada Sila Ke-5 Pancasila yaitu "Keadilan Sosial Bagi Seluruh Rakyat Indonesia."

Tujuan mewujudkan kesejahteraan bagi seluruh rakyat Indonesia harus dilaksanakan pula dalam kegiatan pembangunan ekonomi negara. Tujuan tersebut dituangkan lebih lanjut dalam Batang Tubuh pada Pasal 33 UUD NRI Tahun 1945, yaitu:

(1) Perekonomian disusun sebagai usaha bersama berdasar atas asas kekeluargaan.

(2) Cabang-cabang produksi yang penting bagi negara dan yang menguasai hajat hidup orang banyak dikuasai oleh negara.

(3) Bumi, air, dan kekayaan alam yang terkandung di dalamnya dikuasai oleh negara dan dipergunakan untuk sebesar-besarnya kemakmuran rakyat.

(4) Perekonomian Indonesia diselenggarakan berdasar atas demokrasi ekonomi dengan prinsip kebersamaan, efisiensi berkeadilan, berkelanjutan, berwawasan linkungan, kemandirian, serta dengan menjaga keseimbangan kemajuan dan kesatuan ekonomi nasional.

(5) Ketentuan lebih lanjut mengenai pelaksanaan pasal ini diatur dalam undangundang.

Keempat ayat dalam rumusan Pasal 33 UUD NRI Tahun 1945 telah menetapkan corak kebijakan ekonomi Indonesia yang menjadi acuan dan rujukan dalam mengembangkan setiap kebijakan pembangunan ekonomi nasional. Sebab, UUD NRI Tahun 1945 sebagai konstitusi atau hukum dasar tertulis tertinggi, yang memuat kebijakan ekonomi tertinggi bersifat mengikat dan keberlakuannya memaksa untuk dituangkan dalam bentuk peraturan perundang-undangan dibawahnya. ${ }^{1}$

Corak kebijakan ekonomi dalam Pancasila dan UUD NRI Tahun 1945 yang harus menjadi rujukan dan acuan dalam berbagai kebijakan yang dikeluarkan Pemerintah dalam kegiatan pembangunan ekonomi nasional, menunjukkan bagaimana politik hukum nasional pembangunan ekonomi Indonesia. Politik hukum nasional adalah pedoman dasar bagi segala bentuk dan proses perumusan, pembentukan dan pengembangan hukum di tanah air.

${ }^{1}$ Jimly Asshiddiqie, Konstitusi Ekonomi (Jakarta: Kompas, 2016), h. xi. 
Politik hukum menjadi salah satu unsur penting saat menciptakan sejumlah kebijakan dan regulasi yang akan diberlakukan di masyarakat. Politik hukum seolah menjadi suatu gambaran atas suatu sistem hukum yang dikehendaki oleh Pemerintah maupun oleh masyarakat, serta perkembangan zaman yang terjadi secara global dalam suatu kebijakan dan regulasi yang dirumuskan oleh Pemerintah. Menurut Satjipto Rahardjo, politik hukum merupakan aktivitas memilih dan cara yang hendak dipakai untuk mencapai suatu tujuan sosial dan hukum tertentu dalam masyarakat. ${ }^{2}$

Dalam upaya menjadikan hukum sebagai proses pencapai cita-cita dan tujuan negara, politik hukum nasional harus berpijak pada kerangka dasar sebagai berikut: ${ }^{3}$

1) Politik hukum nasional harus selalu mengarah pada cita-cita bangsa, yakni masyarakat adil dan makmur berdasarkan Pancasila.

2) Politik hukum nasional harus ditujukan untuk mencapai tujuan negara yaitu melindungi segenap bangsa dan seluruh tumpah darah Indonesia, memajukan kesejahteraan umum, mencerdaskan kehidupan bangsa, melaksanakan ketertiban dunia berdasarkan kemerdekaan, perdamaian abadi, dan keadilan sosial.

3) Politik hukum nasional harus dipandu oleh nilai-nilai Pancasila sebagai dasar negara, yaitu berbasis moral agama, menghargai dan melindungi hak-hak asasi manusia tanpa diskriminasi, mempersatukan seluruh unsur bangsa dengan semua ikatan primordialnya, meletakkan kekuasan di tangan rakyat, dan membangun keadilan sosial.

4) Politik hukum nasional harus dipandu oleh keharusan untuk melindungi semua unsur bangsa demi integrasi atau keutuhan bangsa yang mencakup ideologi dan teritori, mewujudkan keadilan sosial dalam ekonomi dan kemasyarakatan, mewujudkan demokrasi (kedaulatan rakyat) dan nomokrasi (kedaulatan hukum), menciptakan toleransi hidup beragama berdasarkan keadaban dan kemanusiaan.

5) Sistem hukum nasional yang harus dibangun adalah sistem hukum Pancasila, yakni sistem hukum yang mengambil atau memadukan berbagai nilai kepentingan, nilai sosial, dan konsep keadilan ke dalam satu ikatan hukum prismatik dengan mengambil unsur-unsur baiknya.

Beberapa bulan sebelum akhir tahun 2020, Pemerintah mengeluarkan UndangUndang Nomor 11 Tahun 2020 tentang Cipta Kerja (UU Cipta Kerja). UU Cipta kerja ini dilahirkan sebagai upaya merespon kebutuhan kepastian hukum dalam bidang investasi di Indonesia. Kehadiran UU Cipta Kerja dalam bidang investasi merupakan upaya merombak pasal-pasal dalam berbagai undang-undang melalui 1 (satu) undang-undang, dengan kemampuan daya jangkau yang mengatur lintas sektor yang berada di bawah urusan berbagai badan atau kementerian. Konsep atau metode ini dikenal dengan istilah omnibus law. Tujuan dari konsep atau metode omnibus law melalui UU Cipta Kerja adalah, mempercepat konsolidasi aturan-aturan yang bertentangan secara bersamaan, dan menjadi rujukan bagi semua aturan untuk sektor terkait. ${ }^{4}$ Sebelum hadirnya omnibus law melalui UU

2 Satijipto Raharjo, Ilmu Hukum (Bandung: Citra Aditya Bakti, 2000), h. 35.

${ }^{3}$ Jazim Hamidi, Teori Dan Politik Hukum Tata Negara (Yogyakarta: Total Media, 2009), 30-32.

4 Jaja Ahmad Jayus, "Konsep Sistem Hukum Investasi Dalam Menjamin Adanya Kepastian Hukum," Jurnal Litigasi 16, no. 2 (2015): 2906-38. 
Cipta Kerja, upaya omnibus law bidang investasi telah dilakukan melalui Undang-Undang Nomor 24 Tahun 2018 tentang Pelayanan Perizinan Berusaha Terintegrasi Secara Elektronik, yang lebih dikenal dengan Online Single Submission (UU OSS). Namun saat UU OSS diterapkan pun masih terjadi tumpang tindih kewenangan dan regulasi terkait lainnya.

Berbagai langkah deregulasi telah dilakukan dengan melakukan evaluasi dan analisa terhadap berbagai regulasi dan kebijakan mengenai kegiatan investasi. Menurut data Badan Perencanaan Pembangunan Nasional (BAPPENAS), sejak Oktober 2014 sampai dengan September 2018 telah terdapat 434 peraturan perundang-undangan, 347 Peraturan Pemerintah dan 533 Peraturan Presiden di bidang ekonomi. ${ }^{5}$ Namun upaya deregulasi tersebut tetap belum memberikan suatu perbaikan, sebab tumpang tindih dan prosedur perizinan tetap menjadi persoalan yang terjadi. Sehingga kegiatan investasi di Indonesia tetap dikategorikan sebagai negara dengan iklim investasi tidak nyaman. Padahal sesuai dengan sifat kegiatan investasi yang berisiko tinggi, maka sangat dibutuhkan aturan-aturan atau regulasi-regulasi yang mampu menciptakan kepastian, keadilan, dan efisiensi. ${ }^{6}$ Sehingga diharapkan kehadiran omnibus law melalui UU Cipta Kerja, persoalan-persoalan tersebut dalam kegiatan investasi tidak lagi menjadi kendala. Harapan lain dikeluarkannya UU Cipta Kerja ini adalah, nantinya mampu meningkatkan pula ekonomi industri di masyarakat yang dapat membuka lapangan kerja bagi masyarakat pula, sehingga tidak semata-mata bergantung bekerja pada industri yang ada, tetapi mampu menciptakan industri pula.

Permasalahan-permasalahan di atas terlihat dari bagian menimbang UU Cipta Kerja. Tampak latar belakang dikeluarkannya UU Cipta Kerja dengan metode omnibus law, target utamanya adalah ingin mengefisiensikan peraturan-peraturan yang terkait dengan kegiatan investasi, agar lebih dapat menarik minat para investor, baik dalam negeri maupun luar negeri untuk menggiatkan kegiatan investasi melalui sejumlah pasal-pasal yang dituangkan. Kendati dengan latar belakang demikian, dalam setiap perumusan peraturan perundang-undangan yang mengatur tentang kegiatan pembangunan nasional, tidak boleh melenceng dari corak kebijakan atau politik hukum yang telah ditetapkan pada Pancasila, Pembukaan dan Pasal 33 UUD NRI Tahun 1945 sebagai cita-cita dan tujuan pembentukan negara, yaitu mewujudkan keadilan sosial dan kesejahteraan bagi seluruh rakyat Indonesia.

Salah satu prinsip yang menjadi corak kebijakan atau politik hukum pembangunan ekonomi negara menurut Pasal 33 ayat (4) UUD NRI Tahun 1945 yang dituangkan dalam Pasal 2 UU Cipta Kerja adalah prinsip atau asas kebersamaan. Prinsip kebersamaan sebagai upaya mewujudkan cita-cita kesejahteraan dan keadilan sosial bagi seluruh rakyat Indonesia dalam UU Cipta Kerja inilah yang akan dikaji lebih lanjut oleh penulis. Berdasarkan paparan tersebut, maka kajian dalam artikel atau tulisan ini mengangkat beberapa permasalahan hukum, yaitu: Bagaimana penerapan konsep asas/prinsip kebersamaan dalam ketentuan-ketentuan investasi UU Cipta Kerja? Apakah penerapan

${ }^{5}$ Dani Prabowo, “Mengenal ‘Omnibus Law' Yang Akan Dibahas Pemerintah Dan DPR...,” Kompas.com, 2019, https:/ / nasional.kompas.com/read/2019/11/29/13511951/mengenal-omnibus-law-yang-akandibahas-pemerintah-dan-dpr?page=all.

6 Jayus, “Konsep Sistem Hukum Investasi Dalam Menjamin Adanya Kepastian Hukum.” Op. Cit. h. 2908. 
asas/prinsip kebersamaan dalam ketentuan-ketentuan investasi UU Cipta Kerja mengarah pada politik hukum investasi/ekonomi industri semata atau kesejahteraan dan keadilan sosial sebagai politik hukum yang mewarnai kebijakan? Mengapa investasi menjadi suatu kebutuhan yang tidak dapat ditolak dalam suatu pembangunan nasional sehingga menjadi penting untuk dituangkan dalam UU Cipta Kerja?

Dari ketiga pertanyaan di atas maka, sistematika penulisan yang akan dipaparkan adalah, dimulai dari pembahasan mengenai konsep asas/prinsip kebersamaan dalam kegiatan pembangunan perekonomian Indonesia sebagai salah satu politik hukum atau corak kebijakan investasi dalam UU Cipta Kerja. Pemaparan ini dirasa perlu dijelaskan di awal untuk menelusuri konsep asas/prinsip kebersamaan yang menjadi corak kebijakan dalam Pasal 33 UUD NRI Tahun 1945 yang dituangkan lebih lanjut dalam UU Cipta Kerja mengenai investasi, agar dapat mengetahui konsep kebersamaan tersebut diterapkan dalam rangka mewujudkan kesejahteraan dan keadilan sosial, ataukah semata titik berat hanya pada investasi sebagai upaya meningkatkan pertumbuhan ekonomi industri di Indonesia.

Pembahasan kedua adalah mengenai urgensi investasi sebagai upaya peningkatan pembangunan ekonomi. Pembahasan ini akan meninjau investasi dalam konsep pembangunan ekonomi dari sisi ilmu atau studi ekonomi pembangunan. Penelusuran dengan menggunakan sudi ekonomi pembangunan ini dirasa penting karena bidang ilmu atau studi ini merupakan bidang yang khusus membedah hal-hal apa saja yang menjadi indikator dan cara meningkatkan investasi dalam pembangunan ekonomi. Pembahasan bagian kedua ini merupakan kajian yang bersifat interdisipliner, karena menggunakan pendekatan bidang ilmu lain diluar hukum. Tujuannya adalah agar dapat melihat posisi dan peran pentingnya investasi dalam suatu pembangunan dan faktor-faktor apa saja yang mempengaruhi dan dibutuhkan oleh kegiatan investasi dalam suatu pembangunan, sehingga nantinya dapat terlihat bagaimana regulasi yang dibutuhkan.

Pembahasan ketiga, setelah mengetahui bagaimana peran penting investasi dalam suatu kegiatan pembangunan ekonomi negara, maka akan dikaji karakteristik hukum investasi melalui regulasi yang diberlakukan. Pembahasan ini dirasa perlu dikarenakan untuk melihat apakah yang menjadi kepentingan dari ketentuan-ketentuan investasi semata hanya untuk kepentingan investasi ataukah berkaitan dengan kepentingan masyarakat banyak. Sehingga nantinya dapat melengkapi pembahasan pertama mengenai konsep asas/prinsip kebersamaan yang diterapkan atau dituangkan dalam UU Cipta Kerja sebagai corak kebijakan atau politik hukum yang mewarnai UU tersebut.

\section{Metode Penelitian}

Jenis penelitian yang digunakan adalah jenis penelitian yuridis normatif, dengan pendekatan multidisipliner guna membedah konsep investasi dalam suatu pembangunan negara maka dibutuhkan pendekatan dari disiplin ilmu ekonomi studi pembangunan. Kajian ini mengarahkan pada kajian teoretik tentang pandangan ahli berdasarkan teoriteori tertentu. Pada penelitian ini digunakan data sekunder sebagai bahan penelusuran bahan hukum, yang mengkaji teori, prinsip, dan isi kaidah. Hasil analisis kajian berupa deskriptif analitis. 


\section{Hasil dan Pembahasan}

\subsection{Konsep Dan Penerapan Asas/Prinsip Kebersamaan Pada Pasal 33 Ayat (4) Uud Nri Tahun 1945 Sebagai Politik Hukum Dalam Undang-Undang Nomor 11 Tahun 2020 Tentang Cipta Kerja}

Sebelum membahas mengenai bagaimana penerapan prinsip kebersamaan dalam UU Cipta Kerja, maka akan dipaparkan terlebih dahulu apa yang dimaksud dengan prinsip kebersamaan. Kata "kebersamaan" menunjukan kedekatan makna dengan rakyat, karena "kebersamaan" merupakan kata yang berasal dari kata "sama". Arti kata kebersamaan sendiri merupakan kata benda yang menunjukan hal bersama. Sedangkan pengertian bersama merupakan berbarengan atau seiringan yang merupakan bentuk kata kerja. ${ }^{7}$

Dalam kehidupan sehari-hari, kata kebersamaan telah sering dijumpai. Bila kita renungkan dan melihat implementasi kata "kebersamaan" dalam kehidupan masyarakat luas, akan kita temukan pelaksanaan dari kata "kebersamaan" ini sebagai suatu kegiatan yang dilakukan secara bersama-sama. Kebersamaan memang selalu dilakukan oleh banyak orang atau sekumpulan orang tetapi tidak semua kumpulan orang melakukan suatu kegiatan yang memiliki arti kebersamaan. Kendati secara fisik terdapat sekumpulan orang tetapi jiwa dari sekumpulan orang tersebut tidak didasari pada rasa bersama, karena masing-masing dari sekumpulan orang tersebut cenderung hanya ingin memenuhi kebutuhan dan keinginannya sendiri. Bahkan ketika secara fisik sekumpulan orang tidak berada dalam suatu tempat yang sama bukan berarti mereka tidak memiliki rasa kebersamaan, sebab bisa jadi justru mereka bersama-sama melakukan suatu upaya yang menuju pada suatu tujuan yang sama.

Jika kita tarik dalam pelaksanaan pembangunan suatu negara, maka kita dapat melihat setiap warga melakukan peran aktifnya dalam lingkungan masing-masing sesuai dengan kemampuan dan kapasitas yang dimiliki dalam mencapai tujuan kesejahteraan bersama. Kata “kebersamaan” seringkali disamakan dengan kata "gotong royong”, karena keduanya memiliki arti yang kurang lebih sama, yaitu, sebagai suatu kegiatan yang dilaksanakan oleh banyak orang dalam rangka mencapai tujuan yang sama dan hasilnya dinikmati oleh semua orang.

Prinsip kebersamaan merupakan jiwa dari kerjasama. Kerjasama merupakan gotong royong. Koentjaraningrat ${ }^{8}$ dalam bukunya "Kebudayaan, Mentalitas dan Pembangunan" menyatakan gotong royong merupakan suatu sistem pengerahan tenaga kerja tambahan dari luar keluarga, untuk mengisi kekurangan tenaga kerja pada masa-masa sibuk dalam siklus pertanian padi di sawah. Petani tuan rumah hanya menyediakan sarapan pagi dan makan siang. Kompensasi lain tidak ada, tetapi para petani tuan rumah tersebut harus bersedia membantu petani yang membantunya tadi, kalau mereka membutuhkan bantuan tenaganya. Gotong royong membuat pekerjaan menjadi lebih ringan dan dijalankan dengan gembira. Memperkuat tali persahabatan, perasaan senasib sepenanggungan, membangun

${ }^{7}$ Pusat Bahasa Departemen Pendidikan Nasional, Kamus Besar Bahasa Indonesia (Jakarta: Balai Pustaka, 2008), h. 1212.

${ }^{8}$ Koentjaraningrat, Kebudayaan, Mentalitas Dan Pembangunan (Jakarta: Gramedia Pustaka Utama, 2015), h. 57 . 
sikap tolong menolong, membuat sesuatu persoalan yang berat menjadi ringan karena dapat dipikul bersama.

Kebersamaan menjadi suatu asas/prinsip yang dianut di Indonesia, dikarenakan prinsip kebersamaan merupakan pemikiran yang menjadi bingkai kegiatan dalam bernegara di Indonesia. Sebab, Negara Indonesia adalah negara yang asalnya adalah keluarga. Keluarga adalah satu kesatuan pergaulan hidup, yang terdiri dari anggotaanggota yang berbeda-beda satu sama lain, berbeda dalam umur, berbeda dalam jenis kelamin, berbeda dalam kepribadian pula, namun perbedaan dalam kesatuan. Kemudian akan melahirkan suatu kerjasama sukarela dalam semangat persaudaraan, apabila dijalankan dalam kehidupan perekonomian negara memerlukan kerjasama dengan semangat gotong royong menuju kebahagiaan dan kesejahteraan yang senyatanya, akan sangat membutuhkan kebijakan yang berupa antara lain: kebijakan kesempatan kerja penuh, penguatan koperasi untuk mempercepat penambahan harta milik kaum miskin, terutama faktor produksi, dan pelestarian lingkungan hidup. Kebijakan-kebijakan tersebut dapat dijalankan dengan baik apabila terdapat kerjasama dan kebersamaan antara masyarakat, swasta, dan negara. Di dalam hubungan antar warganegara berdasar atas asas kekeluargaan telah menjadi paham Indonesia dalam kehidupan berbangsa dan bernegara. Demokrasi Indonesia bukan dibentuk atas dasar liberalisme dan individualisme tetapi berdasar atas rasa kebersamaan.

Menurut Merphin Panjaitan, 9 berdasarkan pemikiran Soekarno dan Koentrajaraningrat, diambil suatu kesimpulan mengenai prinsip kebersamaan, sebagai berikut: Pertama, dalam kehidupan bersama, termasuk dalam kehidupan kenegaraan, kebersamaan itu dilaksanakan dalam kerja bersama. Semua bekerja, semua menikmati hasilnya dan semua berbahagia. Agar semua dapat bekerja dan menghasilkan, maka lapangan kerja harus tersedia cukup. Penyediaan kesempatan kerja menjadi tanggung jawab bersama masyarakat dan negara. Apabila masyarakat gagal menyediakan kesempatan kerja, maka negara harus mampu menyediakan lapangan atau kesempatan kerja. Hal ini didasarkan dari prinsip subsidiaritas, yang menyatakan fungsi-fungsi yang tidak dapat dilaksanakan sendiri dengan baik oleh masyarakat, negara perlu melakukannya. ${ }^{10} \mathrm{Kedua}$, gotong royong adalah kerja bersama dalam upaya mencukupi kebutuhan dan menghadapi berbagai permasalahan bersama. Kerja adalah pusat kehidupan dan interaksi antar warga masyarakat dan interaksi antar negara-masyarakat yang diwujudkan dalam bentuk kerja bersama. Ketiga, dalam memajukan masyarakat dan negara, kerjasama adalah menjadi kebutuhan bersama, dan untuk itulah perlu dijalin komunikasi antar berbagai masyarakat dengan baik dan saling mepercayai antar berbagai pihak dalam kehidupan kemasyarakatan. Keempat, setiap warganegara akan mendapatkan kesempatan yang cukup untuk kelangsungan hidupnya dan untuk berkembang sesuai

${ }^{9}$ Merphin Panjaitan, Dari Gotong Royong Ke Pancasila (Jakarta: Jala Permata Aksara, 2013), h. 12-13.

${ }^{10}$ Negara hanya melengkapi bukan menggantikan masyarakat, sebab negara melakukan fungsi yang tidak dapat dilakukan sendiri dengan baik oleh masyarakat. Negara membantu masyarakat, dalam berbagai fungsi yang tidak dapat dikerjakan sendiri dengan baik oleh masyarakat. Negara sebagai subsidier terhadap masyarakat. Dari pemikiran ini terbentuklah salah satu prinsip negara demokratis, yaitu prinsip subsidiaritas, dimana negara berfungsi membantu masyarakat, dan berbagai fungsi yang dapat dilaksanakan sendiri dengan baik oleh masyarakat maka negara tidak perlu melakukannya. 
dengan minat dan bakatnya demi kebahagiaan semua. Kelima, kemajuan masyarakat dan negara dapat dinikmati oleh semua warga negara sesuai dengan prestasinya atau minimal sesuai dengan kebutuhannya. Keenam, manusia gotong royong adalah pekerja keras, sederajat, tolong menolong, bantu membantu, hidup bersama dalam kesadaran bahwa manusia tidak dapat hidup sendiri. ${ }^{11}$

Paham kebersamaan sering disebut juga dengan kolektivisme yang sangat berkaitan dengan sosialisme. Istilah kolektivisme dan sosialisme merupakan 2 (dua) istilah yang lebih populer di Uni Soviet, meskipun tidak selalu kedua istilah tersebut dipahami sebagai komunisme. Di Amerika Serikat istilah "kebersamaan" atau kolektivisme ini lebih dikenal dengan istilah "communitarianism" dan tokoh yang mengusung paham communitarinisme ini adalah Amitai Etzioni, yang memberi makna secara teori bahwa kebersamaan dalam konsep communitarinisme adalah bahwa privacy dinyatakan sebagai a social license, sehingga privacy sebenarnya adalah amandated privacy, atau privacy atas izin masyarakat, berdasar nilai-nilai sosial yang berlaku di masyarakat. ${ }^{12}$

Prinsip kebersamaan lahir dalam dari suatu sistem ekonomi pasar sosial. Dimana kegiatan ekonomi digerakkan oleh mekanisme pasar yang dikendalikan oleh pemerintah menuju ekonomi pasar yang efisien, tetapi berkeadilan, sebagaimana yang dirumuskan dalam Pasal 33 Ayat (4) UUD 1945. Ayat dalam pasal ini merupakan bagian yang tidak terpisahkan dengan ayat-ayat sebelumnya, yang mengatur masalah kepemilikan faktor produksi oleh perorangan dibatasi oleh undang-undang, hukum adat dan norma kepentingan umum, kepemilikan publik dan kepentingan komunal. Peran swasta tidak dibatasi selama tidak menyangkut cabang-cabang produksi yang penting bagi negara dan menguasai hajat hidup orang banyak. Lalu peran pemerintah tidak hanya sebatas regulator, tetapi juga melakukan tindakan yang diperlukan dan bahkan menjadi pelaku langsung apabila timbul adanya eksternalitas negatif, kegagalan dalam mekanisme pasar, ketimpangan ekonomi, atau kesenjangan sosial. Kesemua itu dilakukan dalam rangka mencapai tujuan untuk memajukan dan memberdayakan semua pelaku ekonomi secara seimbang dan berkelanjutan menuju pertumbuhan dan pemerataan ekonomi. ${ }^{13}$

Pada dasarnya istilah prinsip kebersamaan yang tercantum dalam Pasal 33 Ayat (4) UUD 1945 yang dipadankan dengan istilah-istilah kerjasama, usaha bersama, kekeluargaan, gotong royong, kerakyatan, kolektif, dan komunitarian, merupakan istilah yang kurang lebih mengandung pengertian yang sama saja. Penggunaan istilah-istilah tersebut sebenarnya adalah berusaha untuk menghindari kelemahan-kelemahan yang terdapat dalam sistem kapitalis dan sosialis. Prinsip kebersamaan pada dasarnya adalah prinsip yang mengembangkan pandangan terhadap paham-paham kapitalis dan sosialis. Inilah yang kemudian menjadikan kebijakan-kebijakan yang diterapkan di Indonesia lebih merupakan kebijakan intervensionisme yang dikembangkan untuk mengatasi kelemahan dalam mekanisme pasar agar berkeadilan. ${ }^{14}$

\footnotetext{
11 Panjaitan, Dari Gotong Royong Ke Pancasila, h. 11-12.

12 Amitai Etzioni, The Limits of Privacy (New York: Basic Book, 1999), 196-197.

13 Asshiddiqie, Konstitusi Ekonomi, h. 357.

14 Asshiddiqie, Ibid. h. 358.
} 
Dari prinsip kebersamaan yang menjadi arah dan petunjuk dari setiap pembuatan dan pengambilan kebijakan, akan melahirkan suatu wujud nyata yaitu usaha bersama. Menurut Kamus Besar Bahasa Indonesia, usaha bersama adalah usaha yang dilakukan secara bersama-sama dalam mencapai suatu hasil.

Menurut Sri Edi Swasono, pada dasarnya prinsip kebersamaan menempatkan posisi rakyat sebagai sentral-substansial (sebagai subjek), bukan tereduksi menjadi marginal-residual (sebagai objek). Prinsip kebersamaan merupakan kerjasama gotong royong. Kerjasama (cooperation) adalah kekuatan tandingan terhadap persaingan (competition). Cooperation adalah wujud dasar mutualisme (prinsip kebersamaan), sebagai esensi dan transaksi ekonomi. Kerjasama dan gotong royong membentuk sinergi ekonomi dan meningkatkan produktivitas yang mampu meningkatkan efisiensi ekonomi. ${ }^{15}$

Prinsip kebersamaan yang dianut di Indonesia, merupakan suatu prinsip yang berlandaskan pada konsep sistem ekonomi Pancasila yang dapat dilihat dari 3 (tiga) tingkatan sekaligus, yaitu, ontologis, epistemologis, dan aksiologis. Secara ontologis, keberadaan sistem Ekonomi Pancasila berangkat dari Pancasila sebagai landasan idealnya dan UUD 1945 sebagai landasan konstitusionalnya. Secara epistemologis, sistem ekonomi Pancasila berangkat dari konsepsi paradigmatis yang menempatkan keadilan ekonomi dalam kerangka keseimbangan antara dimensi manusia sebagai mahluk sosial dan mahluk individu, antara hak dan kewajiban, antara dimensi jasmani dan rohani, serta antara pemenuhan hak sipil dan politik dengan hak ekonomi, sosial, dan budaya. Secara aksiologis, sistem ekonomi Pancasila berangkat dari fakta empiris kesenjangan sosial dan ketidaksempurnaan pasar, yang ingin mengatasinya dengan cita-cita tolong menolong secara kekeluargaan (kooperasi). ${ }^{16}$

Posisi Negara atau Pemerintah dalam asas/prinsip kebersamaan adalah ditempatkan dalam posisi sentral dan kuat dalam menciptakan dan mewujudkan kesejahteraan masyarakat secara menyeluruh (public welfare) dan keadilan sosial (social justice). ${ }^{17}$ Artinya Pemerintah dalam setiap pengambilan kebijakan ekonomi harus lebih mengutamakan kepentingan masyarakat atau rakyat Indonesia bukan semata pada kepentingan ekonomi. Menempatkan rakyat sebagai subjek bukan objek kepentingan ekonomi semata.

Dapat dikatakan pula bahwa pembangunan ekonomi dalam konsep asas/prinsip kebersamaan sepertinya berbasiskan pada keunggulan sumber daya produkstif perekonomian dengan memenuhi hak-hak dasar warga negara dan pertumbuhan ekonomi yang berorientasi pada pemerataan. Oleh karenanya posisi Negara adalah merumuskan dalam setiap kebijakan yang dibuat merumuskan kesejahteraan masyarakat.

Kewenangan Negara dalam Putusan Mahkamah Konstitusi Republik PUU Nomor 30/PUU-VIII/2010, meliputi:

${ }^{15}$ Sri Edi Swasono, Ekpose Ekonomika: Mewaspadai Globalisme Dan Pasar Bebas (Yogyakarta: Pustep UGM, 2017), 7-8.

16 Yudi Latif, Negara Paripurna: Historisitas, Rasionalitas, Dan Aktualitas Pancasila (Jakarta: Kompas Gramedia, 2011), h. 588-589.

17 Elviandri, Khuzdaifah Dimyati, and Absori, "Quo Vadis Negara Kesejahteraan: Meneguhkan Ideologi Welfare State Negara Hukum Kesejahteraan Indonesia," Mimbar Hukum 32, no. 2 (2019): 252-66. 
1) Membuat kebijakan (beleid) dan pengurusan (bestuursdaad). Fungsi pengurusan oleh negara dilakukan melalui pemerintah dengan mengeluarkan dan mencabut fasilitas perijinan (vergunning), lisensi (licentie), dan konsesi (consessie);

2) Pengaturan (regelendaad), fungsi pengaturan dilakukan melalui kewenangan legislasi oleh DPR bersama Pemerintah, dan regulasi pemerintah;

3) Pengelolaan (beheersdaad), fungsi pengelolaan dilakukan melalui mekanisme pemilikan saham (share-holding) dan/atau melalui keterlibatan langsung dalam manajemen Badan Usaha Milik Negara atau Badan Hukum Milik Negara sebagai instrumen kelembagaan yang melalui negara untuk digunakan sebesar-besarnya kemakmuran rakyat; dan

4) Pengawasan (toetzichthoudensdaad), fungsi ini adalah negara melalui pemerintah mengawasi dan mengendalikan.

Putusan Mahkamah Konstitusi tersebut didasarkan pada ciri khas ekonomi kerakyatan yang menegaskan peranan vital negara dalam menjalankan negara yang sangat penting dalam sistem ekonomi kerakyatan, dimana peran negara melalui pemerintah tidak hanya terbatas sebagai "penjaga malam" atau pengatur jalannya roda perekonomian, tetapi juga dapat turut serta menyelenggarakan cabang-cabang produksi tersebut dan terlibat secara langsung melalui pendirian Badan Usaha Milik Negara (BUMN), dikarenakan tujuannya adalah untuk menjamin kemakmuran masyarakat bukan hanya milik orang perorangan. Dalam hal ini pengertian Negara dalam arti administrasi, yaitu Pemerintah, yang disebut bestuurszorg atau public service yang berarti menyelenggarakan kepentingan umum, sehingga fungsi administrasi negara adalah sebagai penyelenggara kepentingan umum dengan suatu cara tertentu. ${ }^{18}$

Persoalannya adalah dari rumusan konsep asas/prinsip kebersamaan, sebenarnya menunjukkan sistem ekonomi Indonesia itu berada di tengah-tengah, antara liberalisme dan sosialisme. Akibatnya tafsiran terhadap posisi di tengah-tengah tersebut dalam menentukan kebijakan untuk mewujudkan tujuan dan cita-cita pembentukan negara sangat "bergantung pada kepentingan" yang melatarbelakangi suatu kebijakan. Kebijakan seputar investasi tidak dapat dipungkiri sedikit banyak adalah karena pengaruh globalisasi perdagangan internasional, yang salah satu kewajiban bagi negara yang ikut menyetujui perjanjian perdagangan internasional adalah tidak melakukan diskriminasi peraturan bagi investasi dalam negeri dan investasi asing. Memang kebijakan-kebijakan dalam investasi (khususnya investasi asing) tidak lepas dari pengaruh liberalisasi perdagangan bebas yang berlaku secara global. Pengaruh tersebut memberikan dampak dilematis dan konflik kepentingan, di satu sisi, Indonesia harus membuat peraturan atau ketentuan-ketentuan yang memberikan kemudahan bagi para pelaku investasi khususnya perusahaanperusahaan multinasional, tapi di sisi lain ketentuan yang dikeluarkan tidak boleh bertentangan dengan Pancasila dan UUD NRI Tahun 1945. Pada intinya, sebenarnya liberalisasi investasi ini ingin memberikan perlindungan penuh kepada pemilik modal atau

18 J. Wayong and Achmad Ichsan, Fungsi Administrasi Negara (Jakarta: Djambatan, 1983), h. 5-6. 
investor, serta mengurangi sedikit mungkin hak Pemerintah untuk mengendalikan arus modal. ${ }^{19}$

Bagaimana peran negara dalam kegiatan investasi yang tertuang dalam UU Cipta Kerja? Tampaknya jika dilihat dalam Bab III dan Bab X UU Cipta Kerja menunjukan peran negara adalah pembuat kebijakan (beleid), pengurusan (bestuursdaad, pengaturan (regelendaad), dan Pengawasan (toetzichthoudensdaad). Fungsi pengurusan oleh negara dilakukan melalui pemerintah dengan mengeluarkan dan mencabut fasilitas perijinan (vergunning), lisensi (licentie), dan konsesi (consessie). Sedangkan penerapan asas/prinsip kebersamaan yang diatur dalam ketentuan investasi pada UU Cipta Kerja adalah masih sebatas memberikan kesempatan berusaha melalui pemberian-pemberian izin investasi dan berusaha kepada masyarakat agar diharapkan dengan pemberian izin investasi dan berusaha masyarakat akan dapat menciptakan lapangan kerja yang lebih banyak lagi. Sehingga tampak memang Negara sangat mengharapkan masuknya modal dari masyarakat melalui sejumlah pembukaan usaha baik berskala besar hingga usaha menengan kecil dan mikro, baik perseorangan maupun koperasi.

\subsection{Peran Investasi Dalam Suatu Pembangunan Ekonomi Nasional}

Berdasarkan uraian sub pembahasan sebelumnya, bahwa asas/prinsip kebersamaan dalam UU Cipta Kerja bidang investasi adalah memberikan kesempatan seluas-luasnya bagi masyarakat untuk melakukan investasi melalui usaha atau ekonomi industri, maka jelas investasi memiliki peran yang sangat penting dalam kegiatan pembangunan ekonomi suatu negara.

Hampir semua ahli ekonomi menekankan pada arti penting pembentukan modal (capital formation) sebagai penentu utama pembangunan dan pertumbuhan ekonomi. Arti pembentukan modal ialah bahwa masyarakat tidak mempergunakan seluruh aktivitas produktifnya saat ini untuk kebutuhan dan keinginan konsumsi, tetapi menggunakan sebagian saja untuk pembuatan barang modal yang dapat dengan cepat meningkatkan manfaat upaya produktif. Inti proses tersebut adalah pengalihan sebagian sumberdaya yang sekarang ada pada masyarakat ke tujuan untuk meningkatkan persediaan barang modal yang dapat digunakan di masa depan. ${ }^{20}$

Pembentukan modal atau pengumpulan modal dipandang sebagai faktor utama dalam pembangunan ekonomi. Pembentukan atau pengumpulan modal salah satunya melalui investasi. Fitzgerald ${ }^{21}$ mengartikan investasi adalah, aktivitas yang berkaitan dengan usaha penarikan sumber dana yang dipakai untuk mengadakan barang modal pada saat sekarang, dan barang modal akan menghasilkan aliran produk baru di masa yang akan datang, dalam definisi ini investasi dikonstruksikan sebagai sebuah kegiatan untuk menarik sumber dana yang digunakan untuk pemberian barang modal, dan barang modal tersebut menghasilkan produk baru. Sedangkan menurut Kamaruddin Ahmad, bahwa yang dimaksud dengan investasi, adalah menempatkan uang atau dana dengan harapan

${ }^{19}$ An An Chandrawulan, Hukum Perusahaan Multinasional, Liberalisasi Hukum Perdagangan Internasional, Dan Hukum Penanaman Modal (Bandung: Alumni, 2011), h. 15.

${ }^{20}$ M L Jhingan, Ekonomi Pembagunan Dan Perencanaan (Jakarta: Raja Grafindo Persada, 2013), h. 337.

21 Salim and Budi Sutrisno, Hukum Investasi Di Indonesia (Jakarta: Rajagrafindo Persada, 2008), h. 31. 
untuk memperoleh tambahan atau keuntungan tertentu atas uang atau dana dengan tujuan untuk memperoleh keuntungan sebagaimana yang diharapkan. ${ }^{22}$

Dari definisi tersebut, terlihat peran investasi atau penanaman modal dalam pembangunan ekonomi suatu negara adalah sebagai sumber dana untuk kegiatan-kegiatan produksi yang diharapkan akan memberikan hasil atau manfaat. Oleh karenanya investasi merupakan sektor yang sangat penting dalam pembangunan ekonomi, tidak saja dalam konteks makro, juga dalam konteks mikro. ${ }^{23}$ Investasi merupakan salah satu komponen permintaan akhir dalam perspektif ekonomi makro, yang menjadi indikator keseimbangan internal pada situasi keseimbangan pasar produk. Pada sisi lain, secara mikro investasi mencerminkan dunia usaha, karena sumber investasi adalah dunia usaha, dalam konteks perkembangan hubungan internasional, investasi selalu menjadi topik utama pembicaraan. Setiap kepala negara atau pemerintahan negara selalu memasukkan investasi sebagai tolok ukur keberhasilan hubungan bilateral dan multilateral. Karena begitu pentingnya investasi, maka investasi dinyatakan sebagai mesin penggerak pertumbuhan ekonomi dan pembangunan (engine of growth). ${ }^{24}$

Dalam ekonomi makro, investasi berperan sebagai salah satu komponen dari pendapatan nasional, Produk Domestik Bruto (PDB) atau Gross Domestic Product (GDP). Secara sederhana pengaruh investasi terhadap perekonomian suatu negara tercermin dari pendapatan nasional negara tersebut, investasi berkorelasi positif dengan PDB/GDP. Dapat dikatakan, jika investasi naik, maka PDB/GDP cenderung naik. Atau sebaliknya, jika investasi turun, maka PDB/GDP cenderung turun. Pembentukan investasi merupakan faktor penting yang memainkan peran strategis terhadap pertumbuhan dan pembangunan ekonomi suatu negara. Ketika terjadi investasi, maka akan ada sejumlah modal yang ditanam, ada sejumlah pembelian barang-barang yang tidak dikonsumsi, tetapi digunakan untuk produksi, sehingga menghasilkan barang dan jasa di masa yang akan datang. Oleh karena itu, tingkat pertumbuhan ekonomi yang tinggi dan berkesinambungan pada umumnya didukung oleh peningkatan ekspor dan investasi. ${ }^{25}$

Suatu negara akan berkembang secara dinamis jika investasi yang dikeluarkan jauh lebih besar daripada nilai penyusutan faktor-faktor produksinya. Negara yang memiliki investasi yang lebih kecil daripada penyusutan faktor produksinya akan cenderung mengalami perekonomian yang stagnasi. Stagnasi tergambar dari kondisi perekonomian dengan laju pertumbuhan yang lambat, yang tentunya berdampak pada meningkatnya jumlah pengangguran dan kemiskinan. Kondisi yang sangat tidak diinginkan adalah kondisi stagnasi yang diikuti dengan adanya inflasi yang tinggi pula, sehingga perekonomian negara menjadi stagflasi. Perekonomian negara yang stagflasi sangat dihindari bagi para perencana negara. Untuk itulah formulasi kebijakan ekonomi yang pro investasi disorong terus guna mengatasi masalah stagnasi, sekaligus membalik pelambatan ekonomi agar pertumbuhan ekonomi terus menggeliat. Meningkatnya investasi akan

\footnotetext{
22 Kamaruddin Ahmad, Dasar-Dasar Manajemen Investasi (Jakarta: Rineka Cipta, 1996), h. 3.

${ }^{23}$ Jonker Sihombing, Hukum Penanaman Modal Di Indonesia (Bandung: Alumni, 2009), h. 45.

${ }^{24}$ Johnny W Situmorang, Menguak Iklim Investasi Indonesia Pasca Krisis (Jakarta: Esensi Penerbit Erlangga, 2011), h. 53-54.

25 Eddy Cahyono, "Investasi Dan Pembangunan Ekonomi," setkab.go.id, 2020, https:/ / setkab.go.id/investasi-dan-pembangunan-ekonomi.
} 
menjamin kontuinitas pembangunan ekonomi, menyerap tenaga kerja dan menekan kemiskinan, yang muaranya akan memacu perbaikan tingkat kesejahteraan rakyat secara keseluruhan, sebagaimana cita-cita didirikannya suatu negara. ${ }^{26}$

Pernyataan di atas didukung pula oleh W.A. Lewis. Yang mengatakan pendorong utama dalam pertumbuhan ekonomi suatu negara adalah: pertama, upaya untuk berhemat secara ekonomis; kedua, peningkatan pengetahuan atau penerapannya di bidang produksi; dan ketiga, peningkatan jumlah modal atau sumber dana. ${ }^{27}$ Salah satu teori ekonomi pembangunan tentang investasi dan tabungan yang sampai sekarang masih digunakan, adalah teori yang dikemukakan oleh Harrod-Domar. Dalam teori tersebut dikatakan bahwa pertumbuhan ekonomi ditentukan oleh tingginya tabungan dan investasi. Kalau tabungan dan investasi rendah maka pertumbuhan ekonomi suatu Negara juga akan rendah. Masalah pembangunan ekonomi pada dasarnya merupakan masalah menambahkan investasi modal, masalah keterbelakangan ekonomi karena masalah kekurangan modal. Ditambahkan pula teori Harrod-Domar memberikan peranan kunci kepada investasi dalam proses pertumbuhan ekonomi, khususnya mengenai watak ganda yang dimiliki investasi. Pertama, investasi menciptakan pendapatan, dan kedua, investasi memperbesar kapasitas produksi perekonomian dengan cara meningkatkan ketersediaan modal. Watak yang pertama dapat disebut sebagai "dampak permintaan" dan watak yang kedua disebut sebagai "dampak penawaran" investasi. ${ }^{28}$

Harrod-Domar membangun modelnya dengan investasi di satu pihak menghasilkan pendapatan dan di pihak lain menaikkan kapasitas produktif, maka laju investasi harus meningkat agar keterkaitan pendapatan negara dan kapasitas produktif pun meningkat. ${ }^{29}$ John W. Head mengemukakan 7 (tujuh) keuntungan investasi, yaitu: 30 pertama, menciptakan lowongan kerja bagi penduduk Negara tuan rumah sehingga mereka dapat meningkatkan kualitas penghasilan dan standar hidup mereka; Kedua, menciptakan kesempatan penanaman modal bagi penduduk negara tuan rumah sehingga mereka dapat berbagi dari pendapatan perusahaan-perusahaan baru; Ketiga, meningkatkan ekspor dari Negara tuan rumah, mendatangkan penghasilan mtambahan dari luar yang dapat dipergunakan untuk berbagai keperluan bagi kepentingan penduduknya; Keempat, menghasilkan pengalihan peralihan pelatihan teknis dan pengetahuan yang dapat digunakan oleh penduduk untuk mengembangkan perusahaan dan industri lain; Kelima, memperluas potensi keswasembadaan negara dengan memproduksi barang setempat untuk menggantikan impor; Keenam, menghasilkan pendapatan pajak tambahan yang dapat digunakan untuk berbagai keperluan, demi kepentingan penduduk negara; dan Ketujuh, membuat sumber daya negara baik sumber daya alam maupun manusia, agar lebih dari pemanfaatan semula.

26 Ibid.

27 Jhingan, Ekonomi Pembagunan Dan Perencanaan. Op. Cit. h. 41.

28 Ibid. h. 229.

${ }^{29}$ Ibid, h. 230-233.

30 Hartini Rahayu, “Analisis Yuridis UU No. 25 Tahun 2007 Tentang Penanaman Modal," Jurnal Humanity 5, no. 1 (2009): 48-60. 
Begitu pula yang dikutip dalam buku Didik J. Rachbini, 31 investasi mempunyai peranan yang sangat penting untuk meningkatkan pertumbuhan ekonomi, Paul M. Jhonson menyebutkan, investasi adalah seluruh pendapatan yang dibelanjakan oleh perusahaan atau lembaga pemerintah untuk barang-barang modal yang akan digunakan dalam aktivitas produktif. Agregasi investasi dalam perekonomian suatu Negara merupakan jumlah total pembelanjaan guna menjaga atau meningkatkan cadangan barang-barang tertentu yang tidak dikonsumsi segera. Barang-barang tersebut digunakan untuk memproduksi barang atau jasa yang berbeda dan akan didistribusikan ke pihak-pihak lain. Oleh karenanya dapat dikatakan, bahwa Investasi atau penanaman modal adalah, pengeluaran atau belanja perusahaan untuk membeli barang-barang modal dan perlengkapan-perlengkapan produksi untuk menambah kemampuan memproduksi barang barang dan jasa jasa yang tersedia dalam perekonomian.

Peran penting investasi inilah yang kemudian dibutuhkan pula dalam pembangunan di Indonesia. Permodalan yang diperlukan oleh Indonesia untuk pencapaian pembangunan ekonomi adalah, dalam bentuk investasi dengan memanfaatkan pemupukan dan pemanfaat modal dalam negeri dan modal luar negeri secara maksimal yang terutama diarahkan kepada usaha-usaha rehabilitasi, pembaharuan, perluasan dan pembangunan baru di bidang produksi barang-barang dan jasa. Oleh karenanya modal dari masyarakat umum dimobilisasi secara maksimal. ${ }^{32}$

Dari uraian yang telah dipaparkan, terlihat betul bahwa penanaman modal atau investasi merupakakan bagian penyelenggaraan perekonomian nasional dan ditempatkan sebagai upaya untuk meningkatkan pertumbuhan ekonomi nasional, menciptakan lapangan kerja, dan mendorong ekonomi kerakyatan. Agar tujuan penanaman modal atau investasi agar dapat tercapai maka faktor-faktor penunjang yang dapat menghambat kegiatan penanaman modal atau investasi harus dapat diatasi. Beberapa faktor yang mempengaruhi investasi, antara lain: ${ }^{33}$

1) Faktor Politik, faktor politik merupakan faktor yang menentukan manakala investor ingin menanamkan modal. Faktor ini sangat menentukan iklim usaha yang kondusif bagi usaha-usaha penanaman modal terutama penanaman modal asing. Kondisi politik suatu negara yang kurang stabil dan tidak menentu akan mengakibatkan menurunnya pula minat para investor untuk berinvestasi.

2) Faktor Ekonomi, faktor ekonomi ini berkaitan dengan iklim usaha dan aspek moneter atau keuangan suatu negara. Biasanya aspek ekonomi ini akan sangat dipengaruhi oleh faktor politik yang terjadi di suatu negara, karena faktor politik mempengaruhi sentimen keuangan suatu negara.

3) Faktor Hukum, faktor hukum mempengaruhi minat investor karena para investor membutuhkan jaminan regulasi yang dapat melindungi kepentingan para investor dan iklim usaha yang stabil serta tidak berbelit-belit. Menurunnya wibawa hukum dalam negara akan mempengaruhi kegiatan investasi. Daya tarik

${ }^{31}$ Didik J Rachbini, Arsitektur Hukum Investasi Indonesia (Analisis Ekonomi Politik) (Jakarta: Indeks, 2008), h. 11.

32 Dhaniswara K Harjono, Hukum Penanaman Modal, Tinjauan Terhadap Pemberlakuan Undang-Undang No.

25 Tahun 2007 Tentang Penanaman Modal (Jakarta: Rajawali Pers, 2012), h. 7.

${ }^{33}$ Hulman Panjaitan, Hukum Penanaman Modal Asing (Jakarta: Ind.-Hill Co, 2003), h. 9-10. 
investor untuk menanamkan modalnya akan sangat tergantung pada sistem hukum yang diterapkan, apakah sistem hukum negara tersebut mampu menciptakan kepastian, keadilan, dan efisiensi.

Disamping faktor-faktor di atas, investasi juga dipengaruhi oleh kondisi eksternal, antara lain tanda-tanda akan terjadi resesi ekonomi di seluruh dunia. Berdasarkan faktorfaktor di atas secara keseluruhan, aspek-aspek yang mempengaruhi investasi dapat dikelompokkan menjadi: ${ }^{34}$

1) Faktor Dalam Negeri, beberapa hal yang mempengaruhi dari dalam negeri, antara lain:

a) Stabilitas politik dan perekonomian;

b) Kebijakan dalam bentuk sejumlah deregulasi dan debirokratisasi yang secara terus menerus dilakukan Pemerintah dalam rangka menggairahkan iklim investasi;

c) Diberikannya sejumlah pembebasan dan kelonggaran di bidang perpajakan, termasuk sejumlah hak lain bagi investor asing yang dianggap sebagai perangsang (insentif);

d) Tersedianya sumber daya alam yang berlimpah seperti minyak bumi, gas, bahan tambang dan hasil hutan di wilayah Indonesia;

e) Iklim dan letak geografis serta kebudayaan dan keindahan alam Indonesia yang merupakan daya tarik sendiri, khusus bagi proyek-proyek yang bergerak di bidang industri kimia, perkayuan, kertas dan perhotelan (tourism); dan

f) Sumber daya manusia dengan upah yang cukup kompetitif, khususnya proyek-proyek yang bersifat padat karya, seperti industri tekstil, sepatu dan mainan anak-anak.

2) Faktor Luar Negeri, yang terdiri dari:

a) Apresiasi mata uang dari negara-negara yang jumlah investasinya di Indonesia cukup tinggi, seperti: Jepang, Korea Selatan, Hongkong dan Taiwan;

b) Pencabutan Sistem Preferensi Umum terhadap 4 negara industri baru di Asia (Korea Selatan, Taiwan, Hongkong dan Singapura); dan

c) Meningkatkan biaya produksi di luar negeri.

Kendati investasi merupakan bagian penting dalam pembangunan ekonomi nasional suatu negara, sehingga berdampak positif, kegiatan investasi juga memiliki dampak negatif. Dampak positif dan negatif dari investasi atau penanaman menurut William A. Fannel dan Josepht $\mathrm{W}$. Tyler adalah sebagai berikut: ${ }^{35}$

1) Dampak Positif :

a) Memberi modal kerja;

b) Mendatangkan keahlian, manajerial, ilmu pengetahuan, modal, dan koneksi pasar;

${ }^{34} \mathrm{Ibid}, \mathrm{h} .10-12$.

${ }^{35}$ Harjono, Hukum Penanaman Modal, Tinjauan Terhadap Pemberlakuan Undang-Undang No. 25 Tahun 2007 Tentang Penanaman Modal. Op. Cit. h. 14-15. 
c) Meningkatkan pendapatan uang asing melalui aktifitas eksporoleh perusahaan multinasional;

d) Penanaman modal asing tidak melahirkan utang baru;

e) Negara penerima tidak merisaukan atau menghadapi risiko ketika suatu investasi yang masuk, ternyata tidak mendatangkan untung dari modal yang diterimanya; dan

f) Membantu upaya-upaya pembangunan kepada perekonomian Negara.

2) Dampak Negatif:

a) Perusahaan multinasional berdampak negatif bagi perekonomian negara penerima;

b) Perusahaan multinasional melahirkan sengketa dengan negara penerima atau dengan penduduk asli miskin setempat;

c) Perusahaan multinasional dapat mengontrol maupun mendominasi perusahan-perusahaan lokal, akibatnya mereka dapat mempengaruhi kebijakan-kebijakan ekonomi atau bahkan kebijakan politis dari negara penerima;

d) Perusahaan Multinasional banyak dikecam telah mengembalikan keuntungakeuntungan dari kegiatan bisnisnya ke negara tempat induksi berada. Praktik seperti ini setidaknya telah mengurangi cadangan persediaan mata uang mata uang asing dari negara penerima;

e) Ada tuduhan perusahaan multinasional yang kegiatan usahanya ternyata telah merusak lingkungan di sekitar lokasi usahanya, terutama negara-negara yang sedang berkembang. Sebabnya perusahaan multinasional telah menggunakan zat-zat yang membahayakan lingkungan-lingkungan atau menerapkan teknologi yang tidak atau kurang memperhatikan kelestarian lingkungan; dan

f) Perusahaan multinasional dikritik telah merusak aspek-aspek positif dari penanaman modal di negara-negara berkembang.

Uraian-uraian di atas telah menunjukkan bahwa dalam studi ilmu ekonomi pembangunan, investasi merupakan bagian yang tidak mungkin dipisahkan dalam suatu pembangunan ekonomi negara manapun. Sebab, tidak semua negara mampu memenuhi kecukupan modal, baik berupa modal sumber daya alam, sumber daya manusia, dan sumber daya keuangan. Didik J. Rachbini menyatakan, ${ }^{36}$ bahwa peranan investasi dalam ekonomi bersifat sangat strategis. Oleh karenanya tanpa investasi yang cukup memadai maka jangan diharapkan ada pertumbuhan ekonomi yang tinggi serta tidak akan pernah terlihat peningkatan kesejahteraan ekonomi yang lebih baik. Dengan kata lain investasi atau penanaman modal adalah suatu keniscayaan. Kegiatan investasi membutuhkan beberapa faktor penunjang, salah satu faktor penting dalam kegiatan investasi adalah faktor hukum. Faktor inilah yang nanti akan dibahas lebih lanjut dalam bagian berikutnya.

\subsection{Peran Dan Karakter Hukum Investasi}

Setelah melihat peran penting investasi yang tidak mungkin dilepaskan dari kegiatan pembangunan ekonomi menurut kajian ilmu ekonomi pembangunan, dan faktor-faktor

${ }^{36}$ Rachbini, Arsitektur Hukum Investasi Indonesia (Analisis Ekonomi Politik). Op. Cit. h. 11. 
yang dapat mendukung kegiatan investasi dalam suatu pembangunan ekonomi negara, maka peran hukum mejadi bagian yang sangat penting pula dalam kegiatan investasi. Sebab dalam perkembangan ekonomi suatu negara, kedudukan dan peranan hukum dianggap sangat penting. Bahkan Jean Jacques Rousseau pada tahun 1775, dalam bukunya "A Discourse on Political Economy", sudah menguraikan keterkaitan antara hukum dan ekonomi. Karena kata ekonomi yang berasal dari "oikos" yang berarti rumah tangga, dan "nomos" yang berarti hukum, sehingga menurut Rosseau, "only the wise and legitimate government of the house for the common good of the whole family. The meaning of the was then extended to the government of that great family, the state." 37

Kebutuhan akan adanya hukum (dalam hal ini diartikan sebagai regulasi) dalam kegiatan pembangunan ekonomi, menurut Alan Brudner dalam buku "Constitutional Goods", menyatakan perlunya hak-hak ekonomi suatu negara yang diatur dalam berbagai peraturan perundang-undangan. Perlindungan hak-hak sosial dan ekonomi merupakan salah satu hal yang dipandang sangat penting. ${ }^{38}$

Hal ini menunjukkan bahwa bagaimanapun sistem ekonomi suatu negara, atau sistem pasar yang digunakan, tetap saja diperlukan intervensi negara dalam bentuk regulasi atau peraturan perundang-undangan yang sangat berpengaruh dalam proses pembangunan ekonomi dan pengendalian pasar bebas. Pengaturan-pengaturan demikian dibutuhkan, karena dalam rangka memberikan jaminan sistem rujukan bersama yang digunakan oleh para pemangku kepentingan dalam kegiatan pembangunan. Pentingnya sejumlah regulasi atau peraturan-peraturan tersebut adalah dalam rangka memberikan kepastian, keadilan dan kemanfaatan, sehingga pada gilirannya nanti dapat membawa kesejahteraan bersama dalam kehidupan masyarakat.

Tanpa kepastian hukum, perekonomian suatu negara tidak akan menumbuhkan kebebasan yang sehat dan berkeadilan dan tanpa kemanfaatan. Perekonomian tidak akan membawa kesejahteraan dan kedamaian. Dengan demikian hukum dapat menjadi "alat" dalam memajukan perekonomian suatu bangsa dalam rangka mencapai kesejahteraan masyarakatnya. ${ }^{39}$ Menurut Roscoe Pound, hukum harus menjadi faktor penggerak ke arah perubahan masyarakat agar lebih baik daripada sebelumnya. Fungsi hukum pada setiap masyarakat (kecuali pada masyarakat totaliter) ditentukan dan dibatasi oleh kebutuhan untuk menyeimbangkan antara stabilitas hukum dankepastian terhadap perkembangan hukum sebagai alat evolusi sosial. Oleh karena itu, hendaknya perubahan dalam kehidupan masyarakat direncanakan dengan baik dan terarah, sehingga tujuan dari perubahan itu dapat tercapai dengan arahan dan perlindungan dari hukum. ${ }^{40}$

Konsep hukum sebagai "alat" adalah salah satu teori yang dicetus oleh Roscoe Pound, "law as a tool of social engineering" yang berkembang di Amerika Serikat. Teori ini memberikan dasar bagi kemungkinan digunakannya hukum secara sadar untuk

${ }^{37}$ Mudrajad Kuncoro, Masalah, Kebijakan, Dan Politik: Ekonomika Pembangunan (Jakarta: Erlangga, 2010), h. 30 .

38 Ibid.

${ }^{99}$ Sri Redjeki Hartono, Hukum Ekonomi Indonesia (Malang: Bayumedia Publishing, 2007), h. 87.

${ }^{40}$ Roscoe Pound, Pengertian Filsafat Hukum (Jakarta: Bhatara, 1972), 42. 
mengadakan perubahan masyarakat, atau dengan kata lain hukum berperan aktif dalam merekayasa perubahan sosial dalam masyarakat. ${ }^{41}$

Dari pandangan Roscoe Pound, tampak hukum seperti berperan aktif untuk melakukan perubahan pada masyarakat. Seolah-olah hukum menciptakan perbuatan dan tindakan agar ada kepastian hukum. ${ }^{42}$ Padahal menurut La Piere, ${ }^{43}$ bahwa faktor yang menggerakkan perubahan hukum itu sebenarnya bukan hukum, melainkan faktor-faktor lain, misalnya ekonomi, teknologi, dan sebagainya. Dalam pembangunan yang dilakukan di suatu tempat, terlihat bahwa jika suatu saat memang terjadi perubahan masyarakat karena adanya pembangunan yang dilakukan sesuai dengan yang dikehendakinya, sehingga hukum bukan sebagai faktor penggerak dari perubahan, justru hukum terlihat sebagai akibatnya saja. Dalam kegiatan pembangunan, sebelum hukum muncul dan berperan sebagai alat rekayasan sosial, sebetulnya telah lebih dahulu bekerja kekuatankekuatan lain, seperti kependudukan, perubahan fungsi-fungsi sosial, atau perubahanperubahan fisik berupa sarana dan prasarana di ruang publik. Setelah kekuatan-kekuatan tersebut berjalan, maka hukum muncul untuk berperan menyelesaikan konflik yang terjadi. Namun perdebatan kedua pandangan tersebut sebenarnya tidak perlu diperpanjang, karena memperdebatkan kedua pandangan tersebut sama halnya memperdebatkan ayam atau telur yang lebih dulu hadir. Kenyataannya hukum dapat berperan dalam masyarakat yang sedang melakukan pembangunan guna terwujudnya perubahan yang lebih baik, apakah hukum tampil dibelakang atau bersamaan dengan kegiatan ekonomi dan teknologi.

Pandangan Roscoe Pound ini mempengaruhi pemikiran Mochtar Kusumaatmadja, yang kemudian mengembangkan konsep dari Roscoe Pound tersebut menjadi teori hukum pembangunan, dengan mengubah kata "alat" menjadi kata "sarana". Pemikiran teori hukum pembangunan oleh Mochtar Kusumaatmadja, tidak hanya dipengaruhi oleh Roscoe Pound, melainkan juga dipengaruhi oleh Herold D. Laswell dan Myres S. Mc Dougal (Policy Approach) ${ }^{44}$

Perubahan hukum yang dilaksanakan di Indonesia, terlepas sebagai "social control" ataupun sebagai "social engineering", mempunyai tujuan untuk membentuk dan memfungsikan sistem hukum nasional yang bersumber pada Pancasila dan UUD NRI Tahun 1945. Artinya, menggunakan hukum sebagai alat rekayasa sosial harus memperhatikan dengan sungguh-sungguh mengenai kemajemukan tata hukum yang berlaku dengan tujuan untuk mewujudkan ketertiban, ketentraman, dan mampu menjamin adanya kepastian hukum, serta dapat mengayomi masyarakat yang berintikan keadilan dan kebenaran. Agar hal ini dapat terlaksana dengan baik, maka perlu dilakukan pembinaan secara berkesinambungan terhadap semua aparatur hukum, melengkapi sarana

${ }^{41}$ Achmad Ali, Menguak Tabir Hukum (Suatu Kajian Filosofis Dan Sosiologis) (Jakarta: Toko Gunung Agung, 2002), h. 101.

42 Abdul Manan, Peranan Hukum Dalam Pembangunan Ekonomi (Jakarta: Kencana Prenada Media Group, 2014), h. 49.

43 Richard T La Piere, Social Change (Englewood Cliff New Jersey: Printice Hall, 1974), h. 69.

44 Shidarta, Karakteristik Penalaran Hukum Dalam Konteks Ke-Indonesiaan (Jakarta: Utomo, 2006), h. 411. 
dan prasarana, serta menyiapkan aturan hukum yang sesuai dengan kepribadian Bangsa Indonesia. ${ }^{45}$

Sebagaimana yang telah dipaparkan di atas, bahwa peran hukum sebagai alat pengendali sosial atau law as a tool of social engineering, adalah untuk mewujudkan ketertiban dan ketentraman dalam kehidupan masyarakat harus sesuai dengan falsafah Pancasila. Falsafah Pancasila menghendaki tercapainya "Keadilan Sosial bagi Seluruh Rakyat Indonesia". Ketentuan ini kemudian dijabarkan lebih lanjut dalam rumusan UUD NRI Tahun 1945. Tujuan untuk tercapainya keadilan sosial melalui peran hukum harus diupayakan secara terus menerus dan keadilan sosial akan terwujud apabila ada keseimbangan antara penyelenggaraan kebutuhan masyarakat secara keseluruhan dan kebutuhan sebagian masyarakat. Dengan kata lain, peran hukum dalam pembangunan sebagai pengendalian sosial bukanlah sekedar memelihara ketertiban, keamanan, dan stabilitas masyarakat dalam arti to keep the peace at all events at any price, tetapi lebih dari itu yakni diarahkan pada cita-cita untuk mencapai kesejahteraan masyarakat Indonesia. ${ }^{46}$

Peran hukum sebagai alat pengendalian sosial melibatkan negara untuk menjalankannya. Oleh karena itu, peranan lembaga eksekutif dan lembaga legislatif dalam membuat aturan hukum mempunyai kewajiban untuk melindungi seluruh kepentingan dan kebutuhan rakyatnya. Begitupun peranan lembaga yudikatif, dalam peranan hukum sebagai alat pengendalian sosial adalah untuk menegakkan aturan hukum yang telah dibuat untuk mewujudkan ketentraman dan kesejahteraan masyarakat. Jadi, terlaksananya hukum sebagai alat untuk pengendalian sosial sangat tergantung pada materi hukum yang dibuat oleh kekuasaan negara dan juga oleh pelaksana hukumnya. ${ }^{47}$

Untuk mewujudkan tujuan menciptakan "Keadilan Sosial bagi Seluruh Rakyat Indonesia", maka pembangunan adalah suatu keniscayaan. Sebab tanpa pembangunan maka kesejahteraan dan keadilan sosial tidak akan tercapai. Secara umum pembangunan lebih tertuju atau dipusatkan pada pembangunan ekonomi. Pandangan atau pemikiran demikian tidaklah keliru, sebab dengan pembangunan ekonomi maka masyarakat akan memiliki kemampuan secara ekonomi untuk lebih mempunyai pilihan lebih luas, kemampuan mengelola sumber-sumber yang ada, meningkatkan martabat sebagai manusia yang layak untuk mencapai kesejahteraan dan kebahagiaan. Oleh karenanya suatu pembangunan yang tidak dapat mencapai itu semua, maka dapat dikatakan pembangunan belum terjadi, hanya sebatas pertumbuhan ekonomi saja. ${ }^{48}$

Menurut Sunaryati Hartono, ${ }^{49}$ peranan hukum dalam pembangunan harus melihat bagaimana bidang-bidang yang diandalkan oleh masyarakat suatu negara, jika masyarakat banyak mengandalkan bidang pertanian, maka akan berbeda peranan hukumnya dengan masyarakat yang mengandalkan bidang industri. Namun jika masyarakat pada suatu negara memang memiliki kemajemukan bidang yang diandalkan, maka peranan hukum

45 Mochtar Kusumaatmadja, Fungsi Dan Perkembangan Hukum Dalam Pembangunan Nasional (Bandung: Bina Cipta, 1970), h. 12.

46 Manan, Peranan Hukum Dalam Pembangunan Ekonomi. Op. Cit. h. 55.

47 Ibid., h. 56.

48 Ibid, h. 57.

49 C. F. G. Sunarjati Hartono, Hukum Pembangunan Ekonomi Pembangunan Indonesia (Bandung: Bina Cipta, 1988), h. 18-19. 
pada masyarakat demikian harus lebih mendetail dalam mengatur segala tindak tanduk masyarakat dan segala lapisan yang ada. Peranan hukum harus mampu mendahului pelaksanaan pembangunan, sehingga memang sangat dibutuhkan perencanaan pembangunan, agar pelaksanaan pembangunan berjalan sebagaimana yang diharapkan.

Peranan hukum dalam investasi, pada dasarnya adalah ketentuan-ketentuan atau aturan-aturan yang mengatur suatu kegiatan penanaman modal yang diberikan oleh orang pribadi (natural person) maupun badan hukum (juridical person), dalam upaya meningkatkan dan/atau mempertahankan nilai modalnya, baik yang berbentuk uang tunai (cash money), peralatan (equipment), aset tak bergerak, hak atas kekayaan intelektual, maupun keahlian. ${ }^{50}$ Oleh karenanya karakteristik aturan-aturan dalam kegiatan investasi atau penanaman modal adalah aturan-aturan yang mengatur kegiatan yang dilakukan oleh seseorang atau badan hukum, menyisihkan sebagian pendapatannya agar dapat digunakan untuk melakukan suatu usaha dengan harapan pada suatu waktu tertentu akan mendapatkan hasil/keuntungan. ${ }^{51}$

Dari pengertian di atas, maka pada dasarnya peranan dan karakteristik hukum dalam kegiatan investasi, adalah aturan-aturan yang dapat memberikan jaminan iklim usaha yang kondusif bagi para pelaku investasi, misalnya mengenai sejumlah aturan di bidang ketenagakerjaan, bidang-bidang usaha yang dapat dikelola oleh investor, perizinan, fasilitas yang diberikan, aturan mengenai biaya-biaya yang dibutuhkan dalam kegiatan investasi yang berdaya saing, aturan mengenai sistem birokrasi yang efektif dan efisien dalam investasi, dan kejelasan hubungan antar instansi terkait bidang investasi. ${ }^{52}$

Pembentukkan hukum investasi dalam suatu negara sangat dipengaruhi oleh teoriteori penanaman modal atau investasi. Menurut Sornarajah, terdapat 3 (tiga) teori dalam investasi yang mempengaruhi pembentukkan hukum investasi, antara lain: ${ }^{33}$

1) Teori Klasik dan Neo Klasik. Menurut teori ini, beberapa faktor yang mempengaruhi pembentukkan hukum investasi, adalah: a). fakta bahwa modal dalam investasi yang tersedia dapat digunakan untuk kepentingan pembangunan dan kepentingan masyarakat, melalui keuntungan yang diperoleh dari para investor melalui pengelolaan usaha dengan cara bagi hasil dan melalui pajakpajak yang dikenakan; b). Invetasi biasanya menggunakan teknologi dan pengetahuan yang dapat dimanfaatkan pengelolaanya oleh negara untuk kepentingan masyarakat; c). Penciptaan lapangan kerja melalui investasi-investasi yang dibuka; dan d). Fasilitas-fasilitas infrastruktur yang akan dibangun oleh Pemerintah dan pelaku investasi. Dari beberapa faktor tersebut maka beberapa regulasi yang dibutuhkan dalam kegiatan investasi berdasarkan teori ini, adalah sejumlah regulasi mengenai dampak lingkungan dan dampak sosial bagi masyarakat akibat pemanfaatan teknologi dalam mengelola kegiatan investasi.

${ }^{50}$ M. Sornarajah, The International Law on Foreign Investment (Chambridge United Kingdom: Cambridge University Press, 2004), 1-2.

${ }^{51}$ Hendrik Budi Untung, Hukum Investasi (Jakarta: Sinar Grafika, 2010), h. 3.

${ }^{52}$ Harjono, Hukum Penanaman Modal, Tinjauan Terhadap Pemberlakuan Undang-Undang No. 25 Tahun 2007 Tentang Penanaman Modal. Op. Cit. h. 68.

${ }^{53}$ Sornarajah, The International Law on Foreign Investment. Op. Cit. h. 51-65. 
2) Teori Kebergantungan (The Dependency Theory). Teori ini lebih berfokus pada perusahaan-perusahaan pelaku investasi, sehingga regulasi-regulasi yang banyak dihasilkan dalam kegiatan investasi menurut teori ini adalah, regulasi seputar perusahaan-perusahaan pelaku investasi.

3) Teori Penengah (The Middle Path Theory). Teori ini mengedepankan peran pemerintah atau negara dalam melakukan strategi pembangunan ekonomi. Intervensi negara sangat dibutuhkan untuk memperbaiki kegagalan pasar, mengatasi penyediaan barang-barang yang dibutuhkan, dan mengontrol stabilitas ekonomi. Menurut kajian Bank Dunia, ada 5 (lima) hal yang harus dilakukan pemerintah dalam membentuk hukum investasi, antara lain: ${ }^{54}$ a). meletakkan dasar hukum yang tepat; b). Menjalankan kebijakan yang tidak merusak ekonomi, termasuk struktur ekonomi makro; c). Menekankan kebijakan penanaman modal di sektor jasa untuk kepentingan umum yang sifatnya dasar dan sektor infrastruktur; d). Melindungi pelaku ekonomi kecil; dan e). Melindungi lingkungan.

Selain ketiga teori di atas, terdapat teori lain yang turut mempengaruhi pembentukkan hukum investasi suatu negara, yaitu teori-teori yang menganalisis dan memberikan pertimbangan mengenai pengawasan teknologi dan hak-hak intelektual. Maka dari berbagai teori tersebut, terdapat beberapa gambaran mengenai bagaimana hukum investasi yang dibutuhkan dalam pembangunan melalui kegiatan investasi. Dapat disimpulkan hukum atau peraturan-peraturan terhadap investasi secara umum yang terdiri dari, yaitu: ${ }^{55}$

1) Peraturan mengenai syarat investasi dan pelaksanaan investasi, yang terkait dengan prosedur perizinan dan pengurusan administrasi;

2) Persyaratan modal untuk melakukan investasi;

3) Persyaratan bidang usaha dan badan usaha;

4) Persyaratan kepemilikan;

5) Pemberian insentif dalam investasi; dan

6) Perlakuan terhadap para investor asing dan investor dalam negeri.

Dari uraian mengenai peran dan karakteristik hukum investasi, jika ditarik ke dalam ketentuan-ketentuan investasi pada UU Cipta Kerja, maka dilihat dari Bab III UU Cipta Kerja, mengatur soal peningkatan investasi dan kegiatan usaha, yang mencakup kemudahan izin usaha, penyederhanaan syarat perizinan usaha, pemanfaatan lahan, dan penyederhanaan syarat investasi merupakan beberapa ketentuan yang sangat dipengaruhi oleh serta menunjukan bagaimana peran dan karakteristik hukum investasi dari teori-teori penanaman modal atau investasi yang telah diuraikan di sub bagian sebelumnya. Salah satunya adalah menurut John Dunning, dalam hukum investasi, terdapat beberapa hal yang sekurang-kurangnya harus diatur dalam berbagai aturan yang berlaku, antara lain: Peraturan mengenai syarat investasi dan pelaksanaan investasi, yang terkait dengan prosedur perizinan dan pengurusan administrasi; Persyaratan modal untuk melakukan investasi; Persyaratan bidang usaha dan badan usaha; Persyaratan kepemilikan; Pemberian

${ }^{54}$ World Bank, Global Development Finance (Washington DC: World Bank, 1997), h. 3.

55 John Dunning, Multinational Enterprises and The Global Economy (Workingham: Addison-Wesley, 1993), h. 567. 
insentif dalam investasi; dan Perlakuan terhadap para investor asing dan investor dalam negeri.

Terkait perizinan usaha, dalam UU Cipta Kerja sekarang penekanannya pada perizinan usaha berbasis risiko yang diatur pada Pasal 7 UU Cipta Kerja. Pada Pasal 7 ayat (1) UU Cipta Kerja menyebutkan bahwa perizinan usaha berbasis risiko dilakukan berdasarkan penetapan tingkat risiko dan peringkat skala usaha. Dalam Pasal 7 ayat (2), dijelaskan penetapan tingkat risiko dan peringkat skala usaha diperoleh berdasarkan penilaian tingkat bahaya dan potensi terjadinya bahaya, yang mencakup aspek kesehatan, keselamatan, lingkungan, pemanfaatan dan pengelolaan sumber daya, dan risiko volatilitas. Sedangkan bagian kegiatan usaha yang berisiko, perizinan usaha hanya cukup mencantumkan Nomor Induk Berusaha (NIB) yang diatur pada Pasal 9 dan Pasal 10 Bab III UU Cipta Kerja. Dalam UU Cipta Kerja, diatur juga mengenai masalah investasi di kawasan ekonomi khusus, kawasan perdagangan bebas dan pelabuhan bebas, Proyek Strategi Nasional, hingga lembaga pengelola investasi di dalam Bab IX.

\section{Kesimpulan}

Berdasarkan uraian yang telah dipaparkan di bagian pembahasan, maka dapat disimpulkan mengenai permasalahan konsep asas/prinsip kebersamaan dalam Pasal 33 ayat (4) UUD NRI Tahun 1945 adalah prinsip atau asas mengenai kerjasama. Sekalipun sering pula disebut juga dengan kolektivisme, pada dasarnya istilah prinsip kebersamaan yang tercantum dalam Pasal 33 Ayat (4) UUD 1945 yang dipadankan dengan istilah-istilah kerjasama, usaha bersama, kekeluargaan, gotong royong, kerakyatan, kolektif, dan komunitarian, merupakan istilah yang kurang lebih mengandung pengertian yang sama saja. Penggunaan istilah-istilah tersebut sebenarnya adalah berusaha untuk menghindari kelemahan-kelemahan yang terdapat dalam sistem kapitalis dan sosialis. Prinsip kebersamaan pada dasarnya adalah prinsip yang mengembangkan pandangan terhadap paham-paham kapitalis dan sosialis. Inilah yang kemudian menjadikan kebijakankebijakan yang diterapkan di Indonesia lebih merupakan kebijakan intervensionisme yang dikembangkan untuk mengatasi kelemahan dalam mekanisme pasar agar berkeadilan. Wujud prinsip/asas kebersamaan yang menjadi salah satu asas dalm UU Cipta Kerja yang diwujudkan dalam sejumlah ketentuan mengenai investasi, masih sebatas memberikan kesempatan berusaha melalui pemberian-pemberian izin investasi dan berusaha kepada masyarakat agar diharapkan dengan pemberian izin investasi dan berusaha masyarakat akan dapat menciptakan lapangan kerja yang lebih banyak lagi. Sehingga fungsi negara dalam UU Cipta Kerja adalah pembuat kebijakan (beleid), pengurusan (bestuursdaad), pengaturan (regelendaad), dan pengawasan (toetzichthoudensdaad). Fungsi pengurusan oleh negara dilakukan melalui pemerintah dengan mengeluarkan dan mencabut fasilitas perizinan (vergunning), lisensi (licentie), dan konsesi (consessie).

\section{Referensi}

Ahmad, Kamaruddin. Dasar-Dasar Manajemen Investasi. Jakarta: Rineka Cipta, 1996.

Ali, Achmad. Menguak Tabir Hukum (Suatu Kajian Filosofis Dan Sosiologis). Jakarta: Toko Gunung Agung, 2002. 
Asshiddiqie, Jimly. Konstitusi Ekonomi. Jakarta: Kompas, 2016.

Cahyono, Eddy. "Investasi Dan Pembangunan Ekonomi." setkab.go.id, 2020. https://setkab.go.id/investasi-dan-pembangunan-ekonomi.

Chandrawulan, An An. Hukum Perusahaan Multinasional, Liberalisasi Hukum Perdagangan Internasional, Dan Hukum Penanaman Modal. Bandung: Alumni, 2011.

Dunning, John. Multinational Enterprises and The Global Economy. Workingham: AddisonWesley, 1993.

Elviandri, Khuzdaifah Dimyati, and Absori. "Quo Vadis Negara Kesejahteraan: Meneguhkan Ideologi Welfare State Negara Hukum Kesejahteraan Indonesia." Mimbar Hukum 32, no. 2 (2019): 252-66.

Etzioni, Amitai. The Limits of Privacy. New York: Basic Book, 1999.

Hamidi, Jazim. Teori Dan Politik Hukum Tata Negara. Yogyakarta: Total Media, 2009.

Harjono, Dhaniswara K. Hukum Penanaman Modal, Tinjauan Terhadap Pemberlakuan UndangUndang No. 25 Tahun 2007 Tentang Penanaman Modal. Jakarta: Rajawali Pers, 2012.

Hartono, C. F. G. Sunarjati. Hukum Pembangunan Ekonomi Pembangunan Indonesia. Bandung: Bina Cipta, 1988.

Hartono, Sri Redjeki. Hukum Ekonomi Indonesia. Malang: Bayumedia Publishing, 2007.

Jayus, Jaja Ahmad. “Konsep Sistem Hukum Investasi Dalam Menjamin Adanya Kepastian Hukum." Jurnal Litigasi 16, no. 2 (2015): 2906-38.

Jhingan, M L. Ekonomi Pembagunan Dan Perencanaan. Jakarta: Raja Grafindo Persada, 2013.

Koentjaraningrat. Kebudayaan, Mentalitas Dan Pembangunan. Jakarta: Gramedia Pustaka Utama, 2015.

Kuncoro, Mudrajad. Masalah, Kebijakan, Dan Politik: Ekonomika Pembangunan. Jakarta: Erlangga, 2010.

Kusumaatmadja, Mochtar. Fungsi Dan Perkembangan Hukum Dalam Pembangunan Nasional. Bandung: Bina Cipta, 1970.

Latif, Yudi. Negara Paripurna: Historisitas, Rasionalitas, Dan Aktualitas Pancasila. Jakarta: Kompas Gramedia, 2011.

Manan, Abdul. Peranan Hukum Dalam Pembangunan Ekonomi. Jakarta: Kencana Prenada Media Group, 2014.

Panjaitan, Hulman. Hukum Penanaman Modal Asing. Jakarta: Ind.-Hill Co, 2003.

Panjaitan, Merphin. Dari Gotong Royong Ke Pancasila. Jakarta: Jala Permata Aksara, 2013.

Piere, Richard T La. Social Change. Englewood Cliff New Jersey: Printice Hall, 1974.

Pound, Roscoe. Pengertian Filsafat Hukum. Jakarta: Bhatara, 1972.

Prabowo, Dani. "Mengenal 'Omnibus Law' Yang Akan Dibahas Pemerintah Dan DPR..." Kompas.com, 
https:/ / nasional.kompas.com/read/2019/11/29/13511951/mengenal-omnibus-lawyang-akan-dibahas-pemerintah-dan-dpr?page=all.

Pusat Bahasa Departemen Pendidikan Nasional. Kamus Besar Bahasa Indonesia. Jakarta: Balai Pustaka, 2008.

Rachbini, Didik J. Arsitektur Hukum Investasi Indonesia (Analisis Ekonomi Politik). Jakarta: Indeks, 2008.

Raharjo, Satijipto. Ilmu Hukum. Bandung: Citra Aditya Bakti, 2000.

Rahayu, Hartini. “Analisis Yuridis UU No. 25 Tahun 2007 Tentang Penanaman Modal." Jurnal Humanity 5, no. 1 (2009): 48-60.

Salim, and Budi Sutrisno. Hukum Investasi Di Indonesia. Jakarta: Rajagrafindo Persada, 2008.

Shidarta. Karakteristik Penalaran Hukum Dalam Konteks Ke-Indonesiaan. Jakarta: Utomo, 2006.

Sihombing, Jonker. Hukum Penanaman Modal Di Indonesia. Bandung: Alumni, 2009.

Situmorang, Johnny W. Menguak Iklim Investasi Indonesia Pasca Krisis. Jakarta: Esensi Penerbit Erlangga, 2011.

Sornarajah, M. The International Law on Foreign Investment. Chambridge United Kingdom: Cambridge University Press, 2004.

Swasono, Sri Edi. Ekpose Ekonomika: Mewaspadai Globalisme Dan Pasar Bebas. Yogyakarta: Pustep UGM, 2017.

Untung, Hendrik Budi. Hukum Investasi. Jakarta: Sinar Grafika, 2010.

Wayong, J., and Achmad Ichsan. Fungsi Administrasi Negara. Jakarta: Djambatan, 1983.

World Bank. Global Development Finance. Washington DC: World Bank, 1997. 